\title{
The Effect Of Teaching Methods (Lecturing, Reading, Cooperative Learning, And Skill Training) And The Level of Intelligence On The تutcomes Of Learning Arabic In High School/ تأثير طرق التعليم (المحاضرة و
}

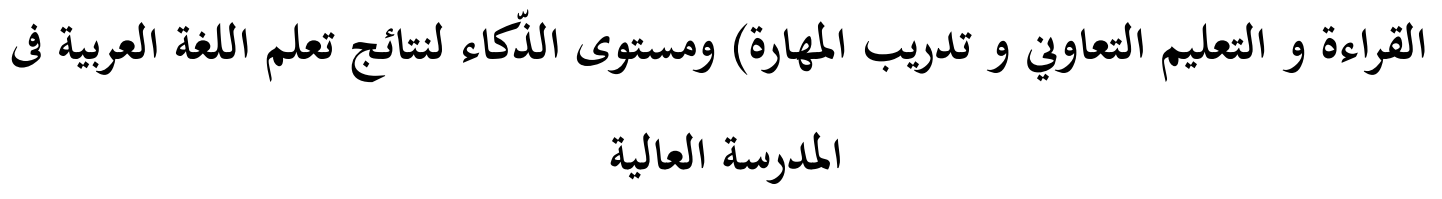

Iga Setawarti

MA Muhammadiyah Surakarta

igaseta@gmail.com

\begin{abstract}
This study aims Knowing the Interaction between teaching methodology and intelligence on learning achievement in Arabic at MAPK MAN 1 Surakarta year lesson 2019/2020. This research applied quantitative. Conducted at MAPK MAN 1 Surakarta from january-february 2020. While the sample is class XI PK. The approach used in this study is a quantitative approach using experimental methods. collection techniques using Observation, Test and Documentation. Analysis techniques using the normality test, homogeneity test, and hypothesis testing. The conclusion of this reasearch is the influence of teaching method (Lecture, Recitation, and Grup in Work, Skill Training) and the level of Intellegence on Arabic learning Achievement in MAPK MAN 1 Surakarta. There were significant differences in Arabic learning using the lecture and recitation methods and students taught using group work methods and skills training. from the calculated $r$ value greater than $r$ table, namely $r h=0.49>0.44=r t$, There was a difference in the learning to students with low IQ or students in 1 ' lower IQ group. the calculated $r$ value greater than the table, namely: $r h=0.78>0.44=r t$, The method of teaching group work and skills training can significantly improve students' learning in the experimental class when compared to the control group. This can be seen from the difference in the average value achieved by the two groups where the experimental group is greater than the control group, namely: 96>94.
\end{abstract}

Keywords : Influence, Teaching Methods, Level of Intelligence, Learning Achievement.

\section{Abstrak}

Penelitian ini bertujuan untuk mengetahui interaksi antara metodologi pembelajaran dan kecerdasan terhadap prestasi belajar bahasa Arab di MAPK MAN 1 Surakarta tahun pelajaran 2019/2020. Penelitian ini bersifat kuantitatif. Dilakukan di MAPK MAN 1 Surakarta dari bulan januari-februari 2020. Sedangkan sampelnya adalah kelas XI PK. Pendekatan yang digunakan dalam penelitian ini adalah pendekatan kuantitatif dengan menggunakan metode eksperimen. Teknik pengumpulan menggunakan Observasi, Tes dan Dokumentasi. Teknik analisis menggunakan uji normalitas, uji homogenitas, dan uji hipotesis. Kesimpulan dari penelitian ini adalah pengaruh metode pembelajaran (Ceramah, Resitasi, dan Kelompok dalam Bekerja, Pelatihan Keterampilan) dan Tingkat Kecerdasan terhadap Prestasi Belajar Bahasa Arab di MAPK MAN 1 Surakarta. Terdapat perbedaan yang signifikan dalam pembelajaran bahasa Arab dengan metode ceramah dan resitasi dan siswa yang 
diajar menggunakan metode kerja kelompok dan pelatihan keterampilan. Dari nilai $r$ hitung lebih besar dari $r$ tabel yaitu $r h=0.49>0.44=r t$, terdapat perbedaan pembelajaran pada siswa ber-IQ rendah atau siswa kelompok ber-IQ 1 'rendah. nilai $r$ hitung lebih besar dari tabel yaitu: $r h=0,78>0,44=r t$, Metode pengajaran kerja kelompok dan pelatihan keterampilan secara signifikan dapat meningkatkan hasil belajar siswa pada kelas eksperimen jika dibandingkan dengan kelompok kontrol. Hal ini terlihat dari perbedaan nilai rata-rata yang dicapai kedua kelompok dimana kelompok eksperimen lebih besar dari pada kelompok kontrol yaitu: $96>94$.

Kata Kunci: Pengaruh, Metode Pembelajaran, Tingkat Kecerdasan, Prestasi Belajar

المقدمة

الإجادة في التعليم هو نتيجة من عملية التعليم والتعلم. تدرك الإجادة في التعليم بعد قيام

التقييم. ليس التفوق مكتسبا فن نفسه، ولكن نتيجة من عملية التعليم. فلا بد أن تبدأ تنمية قدرات الإجادة في أقرب وقت ممكن، من خلال التعليم في المؤسسات التعليمية المختلفة المناسبة لمستوى التطوير عند التلميذ. المعهد كأحد من المؤسسات التعليمية التى تشارك في تنفيذ البرامج الحكومية في بجال التعليم بالإضافة إلى جعل التلاميذ ذوي الأخلاق الكريمة والفكرية.

ومن المواد التعليمية التي تعلمها المعاهد اللغة العربية. فيما يتعلق بوظيفة اللغة العربية كوسيلة للوصول على الإجادة، فيجب أن يكون تدريس اللغة العربية تفسها قادرا على تطوير العقل، والمعرفة، والمهارات وموقف استخدام اللغة. في هذه الحالة يعنى أن تدريس اللغة العربية في المدرسة وفى المدرسة العالية خاصا. من المتوقع أن تقوم بتدريب التلاميذ يتقنون اللغة العربية جيدا ولذلك يطور التلميذ بها على التفكير والنقد في اكتساب المعرفة. الذكاء هو قدرة تعلم مع مهارة للتلاميذ الذين يعيشون مع الظروف التي واجهوا بها. عينت القدرة هذه من خلال مستوي الذكاء العادي وظهرت دائما الكفاءة المتفقة على تنميه النظراء. لا يخلو إما أن يكون هذا التطور مميزة بأوجه تقدم مختلف بين طفل وأخر. ولذلك, قد يكون لطفل في سن معينه مستوي الذكاء أعلى من نظرائه. قال سلامتوا أن مستوي عال من الذكاء سيكون أكثر نجاحا من الذي لديه مستويات سفلى من الذكاء. (ستيفانوس، م ا •ب: . $(7$. الأطفال الذين كانت مستوياهم الفكري أقل من المتوسط من العادية المملة، الغبي، التحنيط والبلهاء تصعب للوصول على النجاح في التعليم. ولن تصل إلى التعليم العالي بقدرقم المحدودة المحتملة. 
الأطفال الذين تكون المستويات الفكري لها ,فوق المتوسط، المتفوقة والموهوب والعبقري عندما تكون بيئة الأسرة ,المجتمع والبيئة التعليمية تدعم فتمكن أن تحقق الإنجاز والنجاح في حياته. (أنور برابو، •

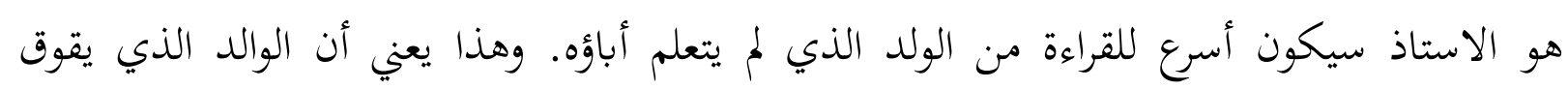

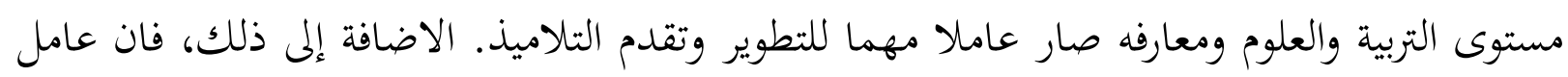

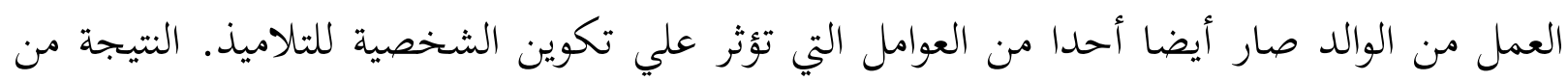

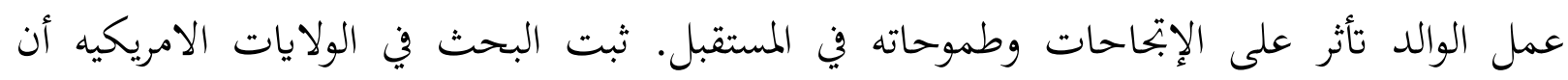

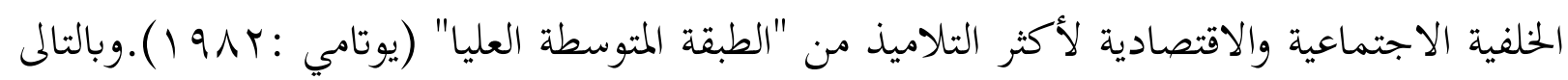
قد كما والجزء من العوامل تتعين على نتائج تعلم التلاميذ بأنفسهم.

المدرسة الثانوية العامة هي مؤسسة تعليمية تصنف بتعليم عام. بالطبع, المعرفة العامة مثل العربية ليست شيئا ميزا، ولذلك فإن المؤسسات التعليمية الدينية مثل المدارس الإسلامية التى عادة ماتكون مختلفة فن المدارس الداخلية الإسلامية أو خارج المدارس الداخلية الإسلامية لديهم بالتأكيد

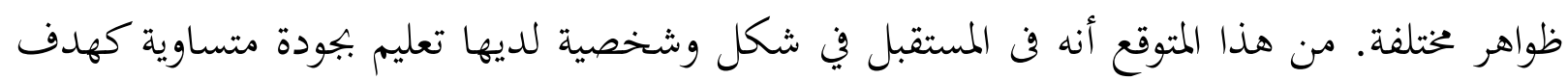

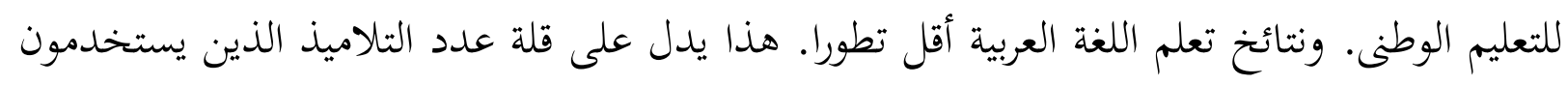

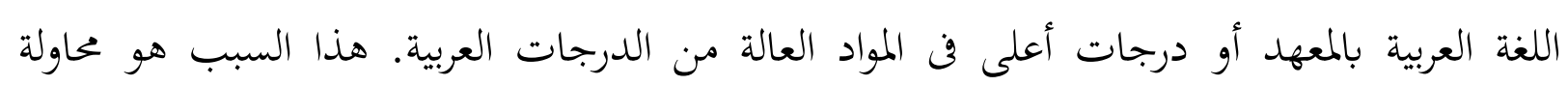

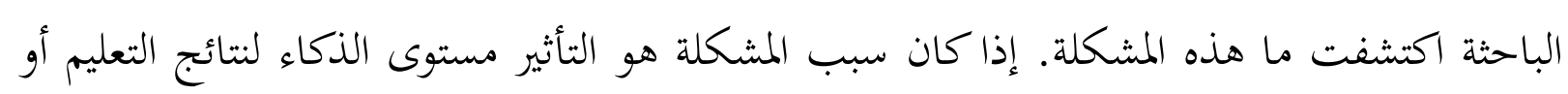

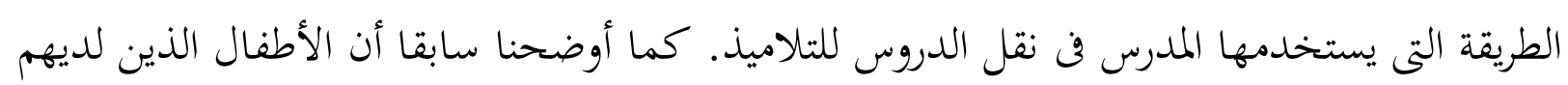

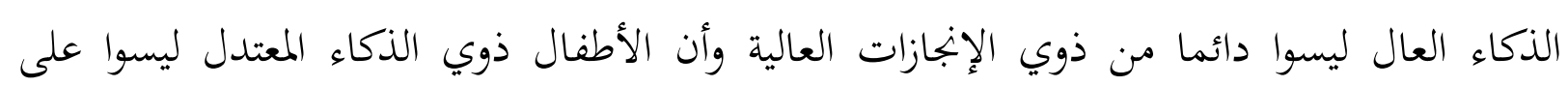
الأرجح من المنجزات العالية لأغم يستطيعون نقل المعرفة التى يقدمها مدرسهم.

منهج البحث

وجري هذا البحث في المدرسة العالية الحكومية الأولى سوراكرتا في الشارع سومباه فيمودا

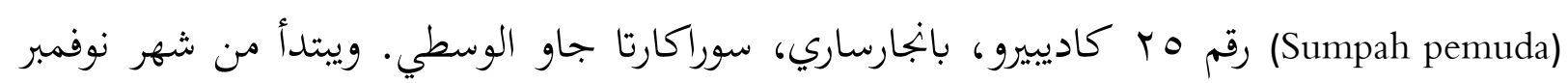

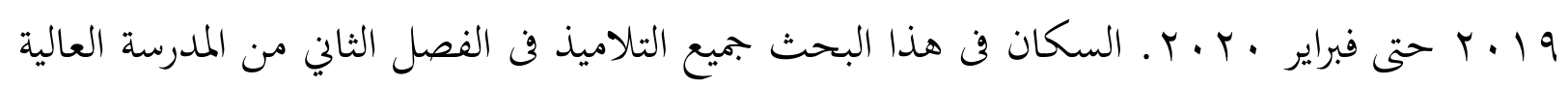


الحكومية الأولى بسوراكرتا. في حين أن العينة الفصل الثاني من البرنامج الخاص. نوع البحث هو فهج

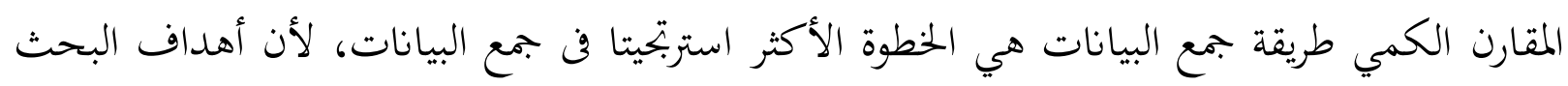

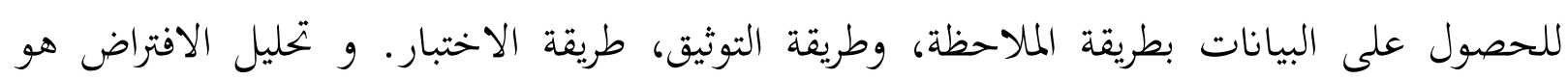
اختبار التسوية، اختبار بتحانس فروض البحث. بعرئه

طريقة تعليم اللغة العربية فوائدها و تأثيرها

قال أحمدي و فراساتيا في كتابه استراتيجية التعلم تشير إلى طريقة التعليم هي معرفة عن طرق

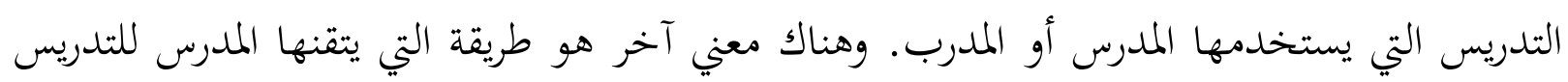

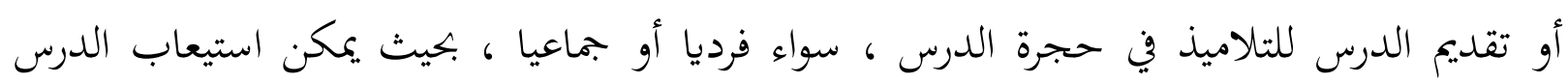

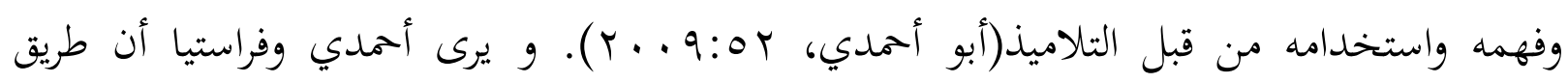

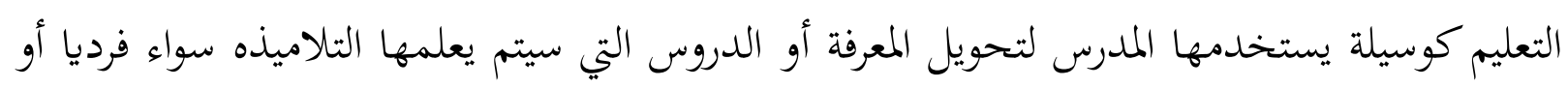

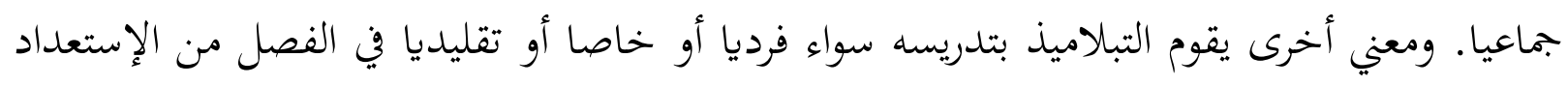

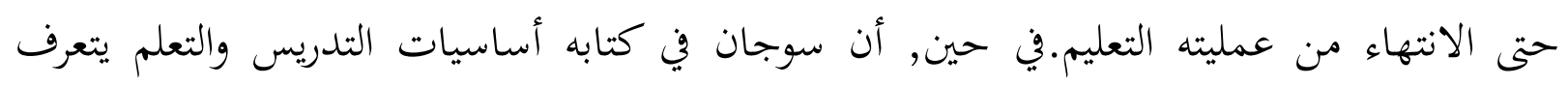
الطريقة وهي طريقة التعليم كوسيلة للمدرس لأقامه العلاقات مع التلاميذ عندما تكون عملية التعليم

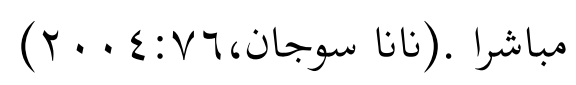

فنتائج التعليم للتلاميذ كما وضح في نظرية نتائج التعليم. قد حددت الباحثة إلى أن الجزء منها

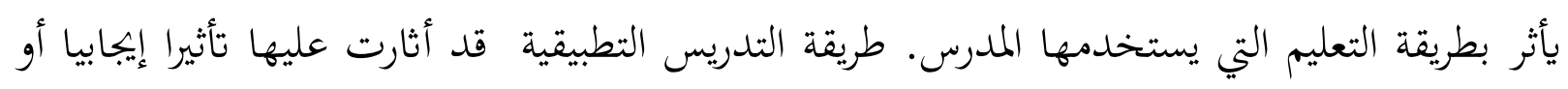

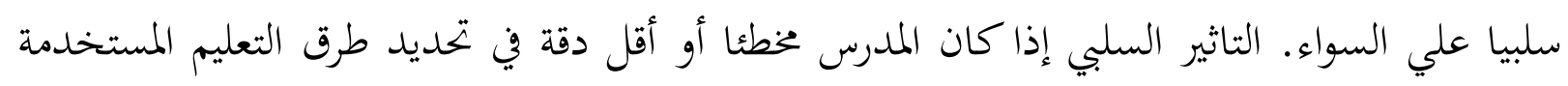
فيصعب في تحويل المواد التي قدمها للتلاميذ ويصعب التلاميذ في فهم الموضوع ويصير الجو التعليمي

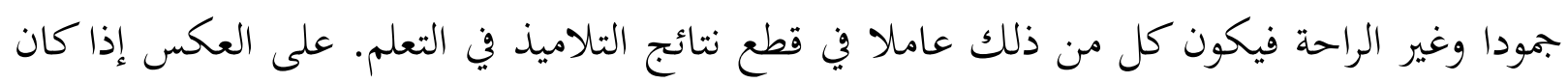
تحديد طرق التعليم للمدرس مناسبة فيسهل ترجمة مواد الدرس للتلاميذ وفقا لمستوي قدرقمم ويسهر 
التلاميذ على نقل وفهم الدرس ويصير الجو التعليمي فعالا. وهذا يمكن أن يؤثر إجابيا لنتائج التلاميذ للتعلم ويكصلوا فوائدها.

في هذا البحث ستجري الباحثة بتربة من المعاملة المختلفه للتلاميذ على طرق التعليم المختلفة في تعليم العربية بين طريقة المحاضرة والتدريب وبين طريقة التعاون والتمارين المهارات. بناء على أقوال المتخصصين فتعرف الباحثة طريقة التعليم التي ستستخدمها في هذا البحث علي النحو التالي: ( ) طريقة المحاضرة وهي طريق للتعليم في نقل مواد الدرس شفهيا. كثيرا ما حدث من التفاعل بين المدرس وتلميذا بالتواصل الشفوي. بكيث يستمع التلاميذ ويميطون كل ما لقاه المدرس من المادة التعليمية. r

تطلق هذه الطريقة غالبا بطريقة الواجبات المنزلية. نعم على الواقع قد يكون التلاميذ أن يقوموا بذلك خارج حصة التعليم ليس فقط في المنزل بل أن يقوموا بها أيضا في المختبرات والمكتبات

$$
\begin{aligned}
& \text { والحدائق التجريبية الخ. }
\end{aligned}
$$

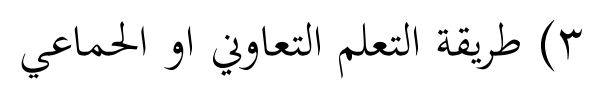

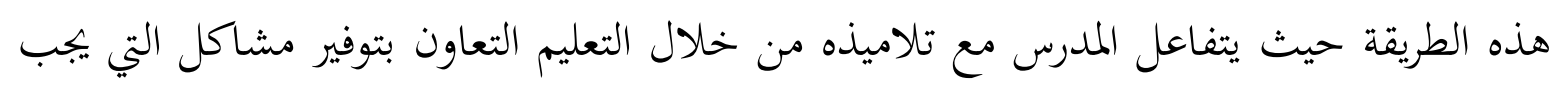

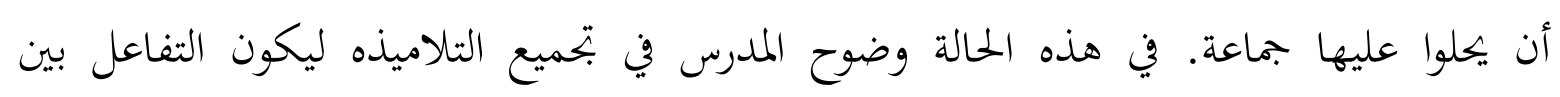
التلاميذ مؤثرا جدا في نجاح عملية التعليم والتعلم.

$$
\text { ع) طريقة تدريب المهاراة }
$$

تعد هذه الطريقة أسلوبا من المدرس لإعطاء واجبات التي تدرب العناصر الحركية للتلاميذ حفظ المفردات مثلا وهلم جرا. في هذه الطريقة لا بد على المدرس أن يهتم بين واجبة وأخرى مختلفين ويهتم ويفهم قيمها الذاتية.

مستويات الذكاء وفوائدها

الذكاء هو أحد مصطلحات علم النفس مشهورًا في المجتمع وغالبًا ما يرتبط بعوامل وراثية.

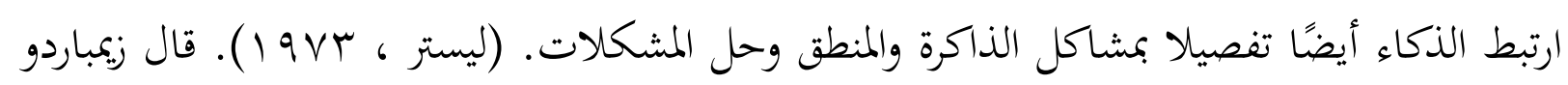


إن الذكاء هو مهارة تنتج عن التجارب وتحقيق القدرات الصحيحة. (زيمباردو ، ع . . ب). الذكاء هو

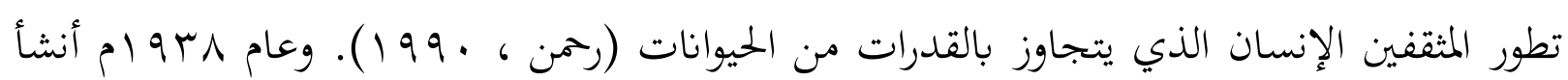
Raven "The Standard Progressive Matrices" التي استخدمت في البحث كمقياس ذكاء التلاميذ (Raven، ومعيد .$(197$.

إن تطوير نظرية الذكاء يتميز في الغالب باسم الشخص. بالطبع هناك استثناءات هناك اسم للزوج والزوجة الذان يصفان إلى نظرية الذكاء في سبيل المثال Thelma Thurstone هذا نقل من Louis و ملما مساهمة في تطوير نظرية القدرة العقلية. (بيرشوف ، ع 90 1: 9 افضلا عن ذلك هناك أشخاص الذين يُعرفون بسهولة باسم مطوري نظرية الذكاء هم: Stern, Spearman, . Thomson, dan Thorndike من الوسم إلى أن يكون أسهل في التذكر من النظرية التي تسمتها بمصطلحات أو عبارات اصطناعية خالية تمامًا من اللمسة الإنسانية.

حوالي عام 1911 قدم Wilhelm Stern نظرية أحادي عامل (Uni-Faktor) عن الذكاء. تُعرف هذه النظرية باسم نظرية القدرات العامة (General Capasity Theory)، وأفكار Stern التي

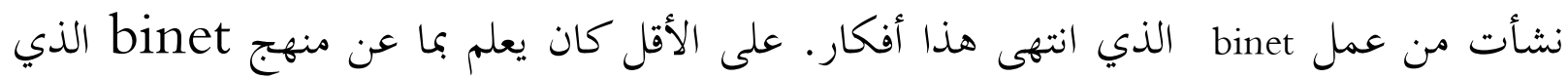

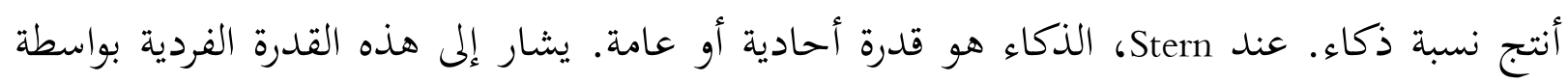
G وبدون شكل محدد (بيرشوف ، ع ع 190 1).

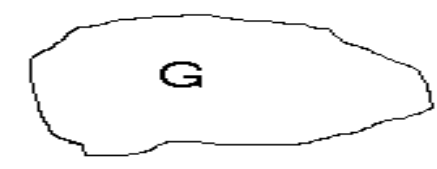

الصورة ץ-1 ا: نظرية أحادي عامل (Uni-Faktor) لستيرن التى تتبين أن الذكاء يتكون من قدرة عامة واحدة فقط. 
هو عالم من علم الرياضيات مولود في بريطانيا الذى يهتم بالذكاء البشري. وعام

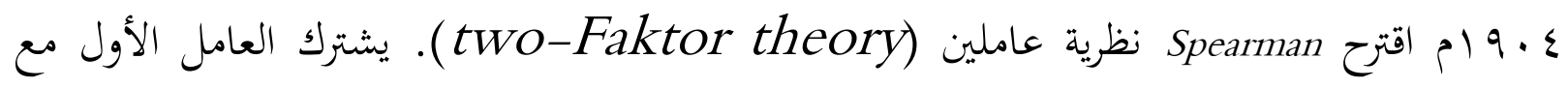
"القدرة العامة" لستيرن. تتضح علاقة التشابه بين نظريتي هذا الشخص في استخدام الحرف الساوي

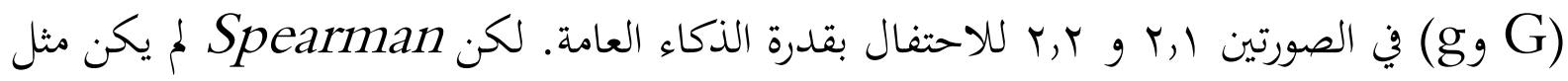
Stern

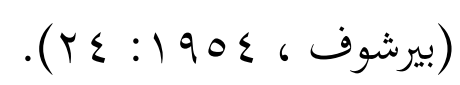

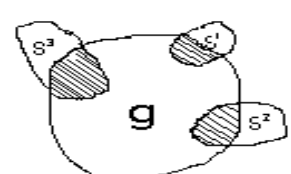

الصورة r, r. نظرية عاملين لسبيرمان، ذات سعة عامة (g) وثلاثة أنواع من الذكاء الخاص ( S1) .(s3 ،

تطرح نظرية طومسون نظرية Thomson لأول مرة عام 7191 ام. هذه النظرية تتعارض مع

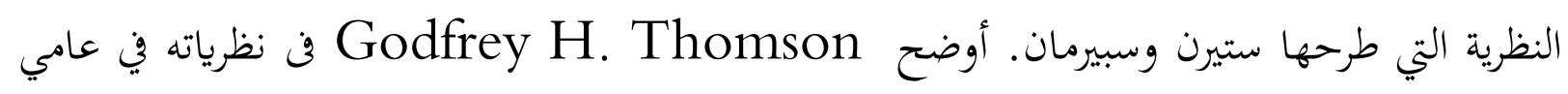
هبو 19 و 19 1. طرح طومسون فجا فريدا ومبدعا، من خلال رمي النرد واختيار البطاقات

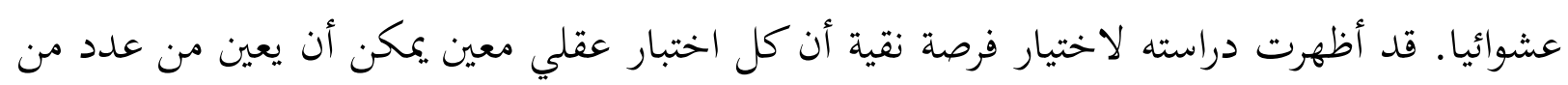
القدرات المجانية. (بيرشوف ، ع ع 90 1: و ب). الفوائد ومقاييس مستوى الذكاء

تعتبر ذكاء أو مستوى ذكاء التلاميذ أنفسهم أحد العوامل التي تؤثر على إنجاز تعليم التلاميذ.

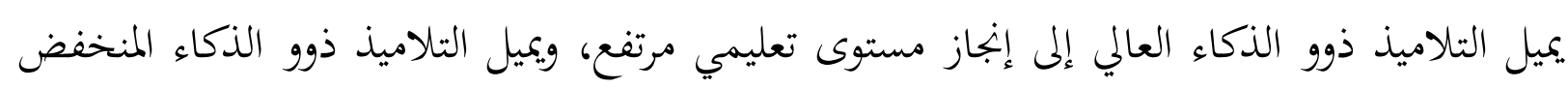

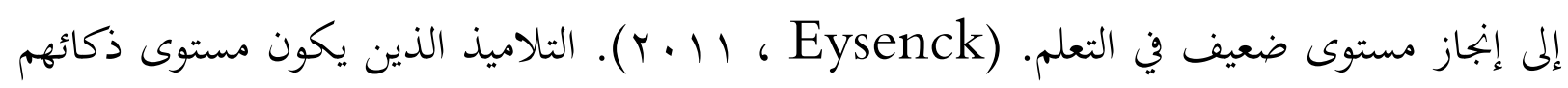
أقل من المتوسط، مملة، العيوب الخلقية، الغبي صعبا أن ينجحوا فيق في المدرسة. ولن يكصلوا على التعليم

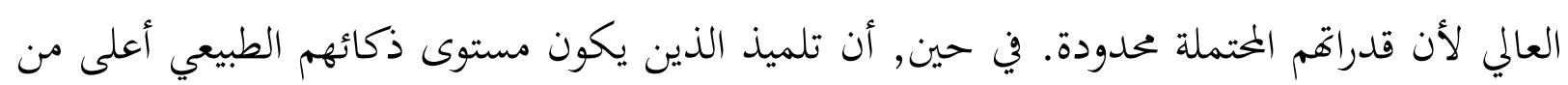
المتوسط، المتفوق، الموهوب والعبقري إذا كانت البيئة الأسرية للمجتمع والبيئة التعليمية تدعمهم فيصلوا

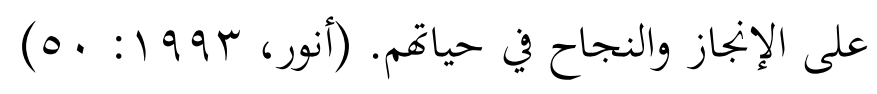


ومن المتغيرات غالبا التي تؤثر على نتائج التعليم هي جنس. قال Tyler أن البنات قد تندر

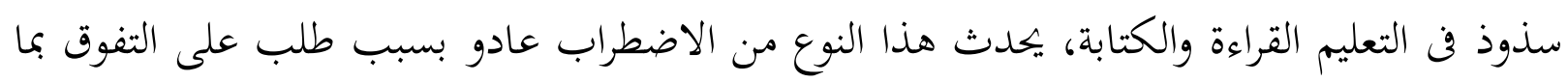

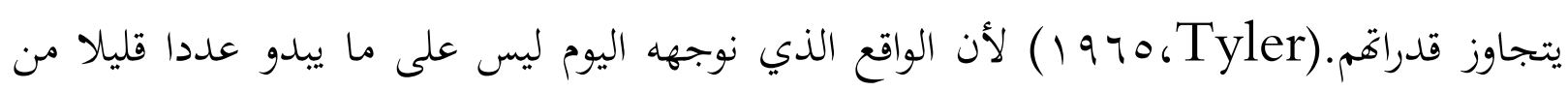

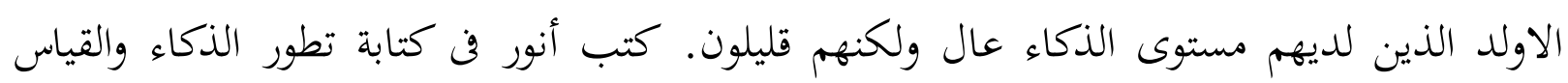
الاولد أنه لتسهيل حساب مستوى الذكاء المطلوب صيغة(1970:T V،Tyler)

$$
\begin{array}{r}
I Q=\frac{M A}{C A} X 100 \\
\text { مؤشر مستوى الذكاء : }
\end{array}
$$

عالم النفس مون الذى استشهد به أنور صنف مستوى الذكاء على النحو

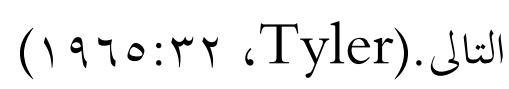

\section{نتائج تعليم اللغة العربية}

قبل أن نفهم نظرية نتائج التعليم، يجب علينا أولاً أن نفهم معنى التعلم نفسه. وذكر

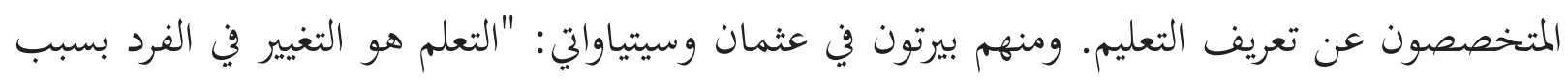

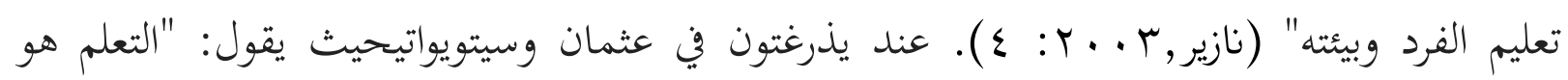

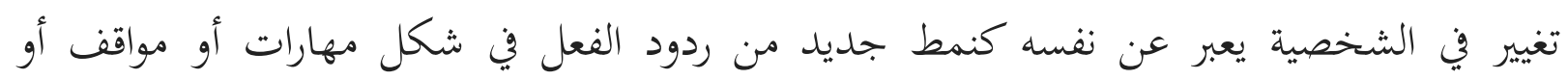

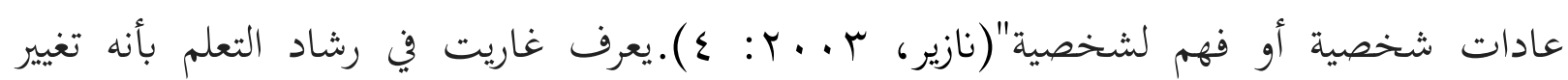

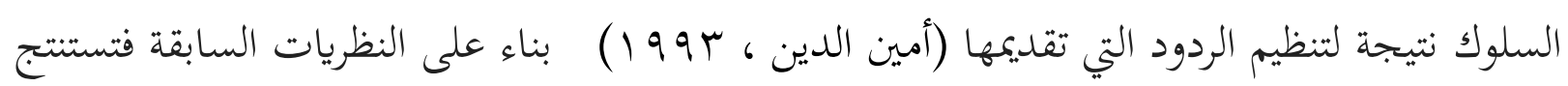
أن التعليم هو عملية تغيير السلوك بحيث لا ينتج فيها هذا التغيير عن عملية نمو فسيولوجي أو عملية

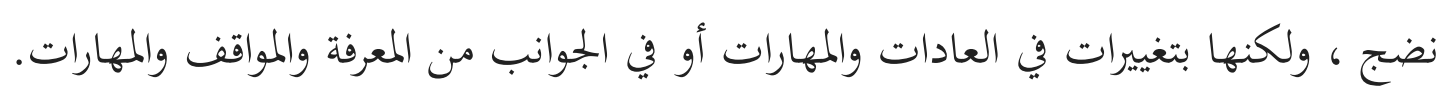

وأما نتائج التعليم هنا إلى درجة نجاح التلاميذ في عملية التعلم لتحقيق أهداف التعلم. في عملية

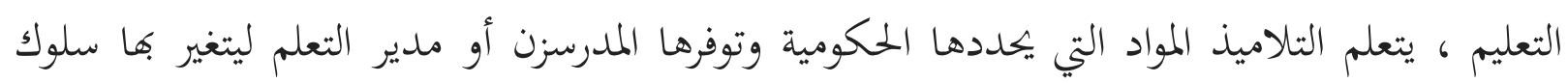

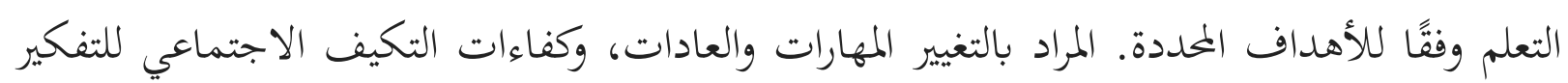


التجريدي وفقا لمجال العلوم التي بتري دراستها. في هذا البحث، المراد بنتائج تعليم اللغة العربية هو مستوى النجاح الذي حققه التلاميذ مدركا من خلال الدرجات التي حصل عليها تلميذا من نتائج اختبار اللغة العربية بعد ان يلقي التلاميذ التدريس باستخدام الطريقة التي اختبرت عليهم.

عند سوريا براتا يتأثر نتائج التعليم بعوامل مختلفة التى تصنف الى وجهات نظر مختلفة، بما في ذلك وجهة نظر موضوع التعلم، وعملية التعلم، وحالة التعلم. نتائج التعلم هو نتيجة لعملية التعلم.

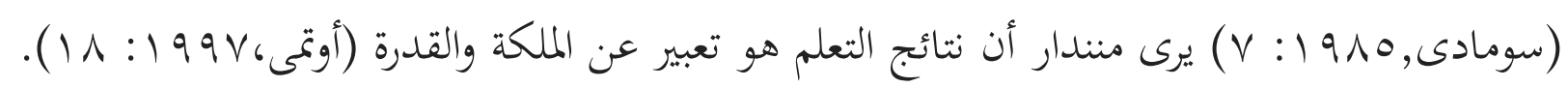

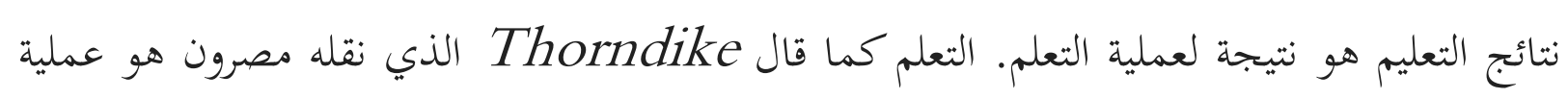

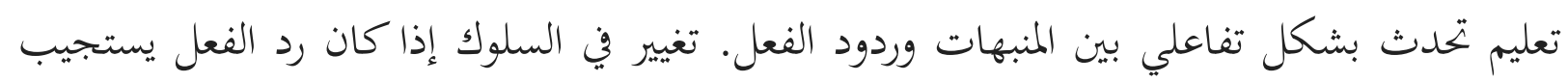
بنجاح للمنبهات (مصرون ، 9VV I ). في نظرية أخرى ، نقل مهاري ويلسون وآخرون عن عملية التعليم هو افم راجعوا من حيث المواد التي بتري دراستها. تحدث العملية في مستويات معينة اعتمادًا

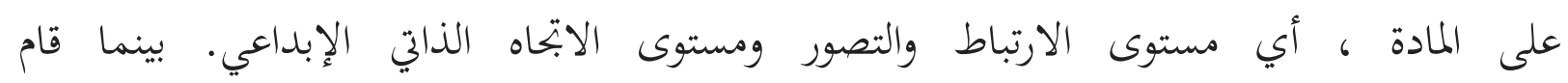
يراجعها من حيث القوانين التي تتبعها العملية نفسها وهي قانون الاستعداد وقانون

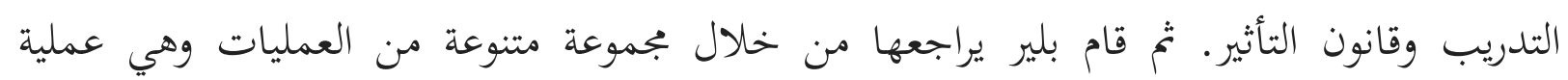

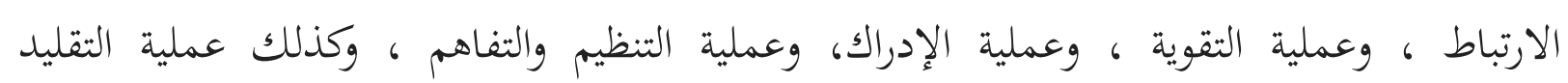

$$
\text { (imitation) }
$$

بناء على النظرية السابقة, خلص مهاري أن عملية التعليم يحدث من خلال دمج بين التجارب

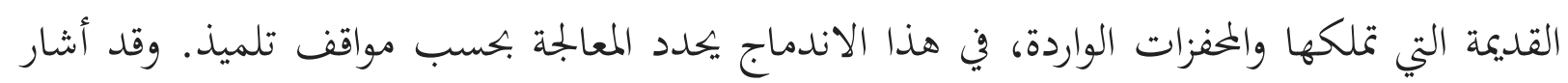
مورغان إلى أن تعريف التعليم نفسه إلى تغيير نسبياً في السلوك كنتيجة للتجربة الماضية (سينجيه،

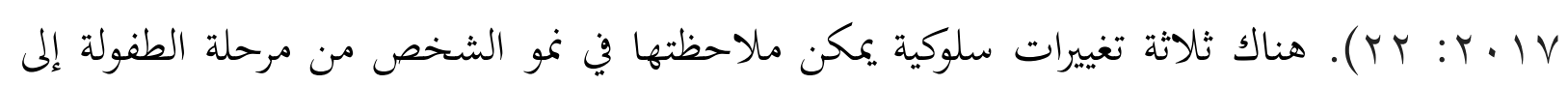
مرحلة الكبار ، وهي: - مبن

$$
\begin{aligned}
& \text { أ. التغييرات التي تحدث بسبب العمليات الفسيولوجية (الفسيولوجية) مثل المريض } \\
& \text { ب. التغييرات التي تحدث بسبب عملية الطهي (النضج) }
\end{aligned}
$$

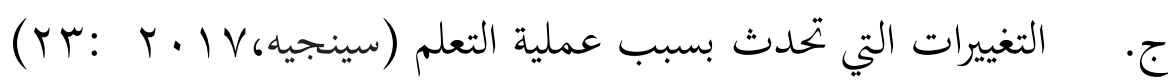


من الشرح السابق قد أشار إلى أن التعلم عبارة عن جهد ييذل لتغيير السلوك الذي يصلحه

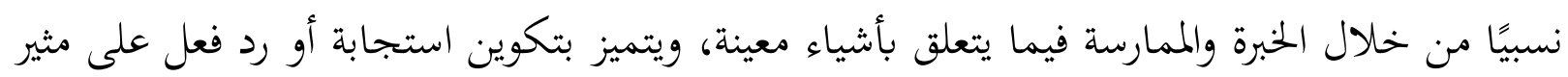

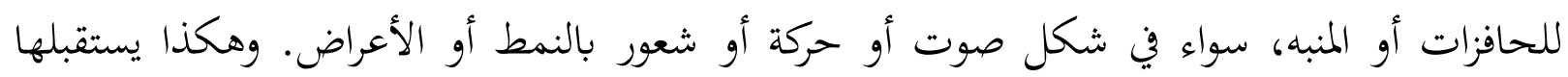

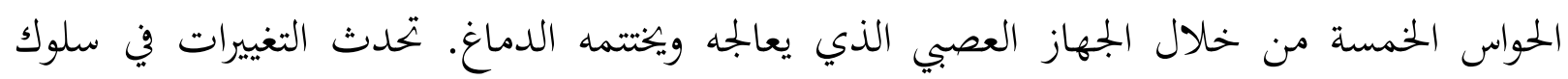
الشخص نتيجة لوجود التحفيز للوصول أهداف معينة، وهي نتائج التعلم. نتائج التعلم من هذا البحث هو نتائج التعلم التي يكصل عليها من خلال عملية التعلم الأكاديمي الذي يركز على أنشطة تلميذ في نقل وفهم المواد التي تدرسها في المدرسة. والمراد بنتائج التعلم هنا هو نتائج تعلم تلميذ من خلال اختبار نتائج التعليم.

تأثير طرق التعليم (الحاضرة و القراءة و التعليم التعاولي و تدريب المهارة) ومستوى الذّكاء لنتائج تعلم اللغة العربية فى المدرسة العالية

كان العينة في هذا البحث التلاميذ فصل الثانى من المدرسة العالية الحكومية الأولى سوراكرتا،

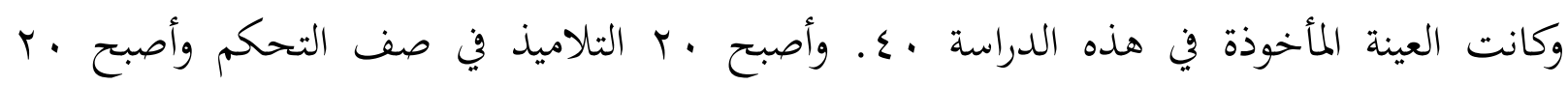
التلاميذ مرة أخرى في الفصل التجريبي. في أول الدراسة إعطاء المواد الدراسة مناسب لتعلم اللغة

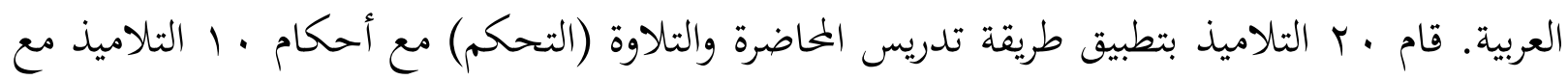
ارتفاع مستوى الذكاء و · ل التلاميذ مع الخفاض مستوى الذكاء. يتم تطبيق ·ـ التلاميذ آخرين تم

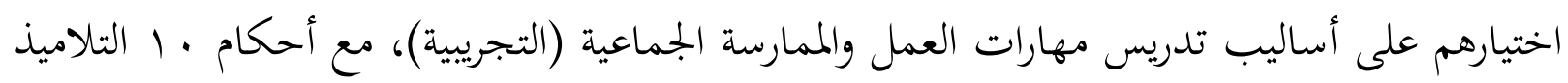
مع ارتفاع مستوى الذكاء و · ل التلاميذ مع الخفاض مستوى الذكاء.

ونتيجة حفظ المفردات عن اختبار في فصل التجربية وفصل المراقبة ستحليل باستخدام اختبار t فإن إذا t حسابي > t جدولي ف Ho مردود و Ha مقبول. لتسهيل في الحساب فتبحث الباحثة عن الأمور التي تتعلق باختبار المواد منها مستوى و متوسط وتيرة ومعيار الإنحراف. والجددول لمساعدة

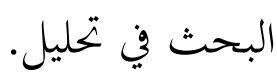
وأما البيانات المحصولة في هذا البحث فهي: 
ا ـ البيانات من مجموعات الدراسة من التلاميذ الذين يتعلمون عن طريق أساليب تدريس محاضرة والمهام تعيين (المجموعة الضابطة). البيانات من هذه المجموعة الدراسة، في البيانات الكمية التي تم الحصول عليها من النتائج قبل بلدء التعلم وبعد التعلم ، ثم حساب متوسط درجة وهنو النتيجة النهائية لنتائج عملية التعلم في هذه الدراسة.

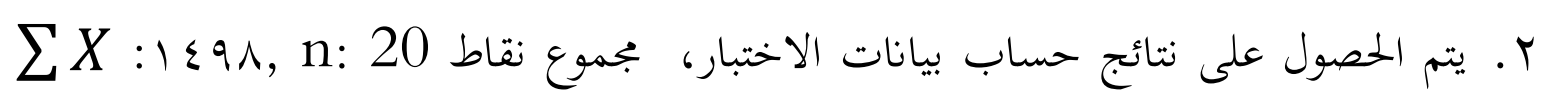

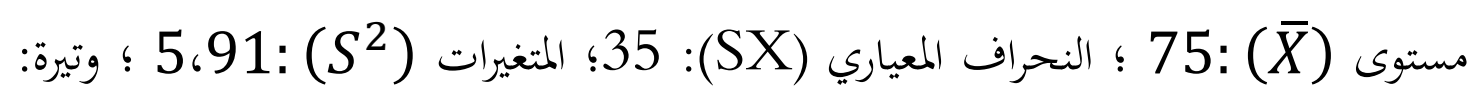

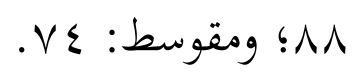
بعد ذلك ، يتم تصنيف متوسط درجات الاختبار في مجموعتي الذكاء من التلاميذ في المجموعتين العليا والسفلى، من المتوقع أن تمثل هذه المجموعة مجموعة من التلاميذ الذين لديهم

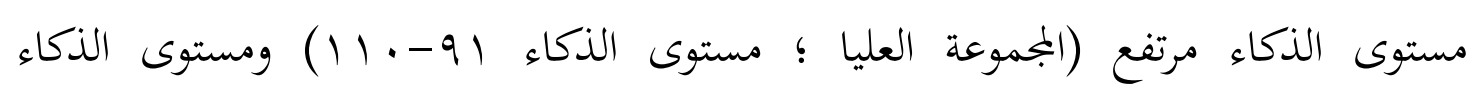

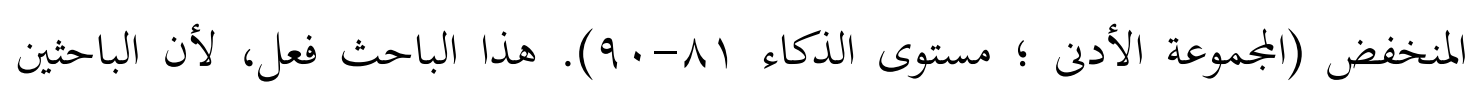

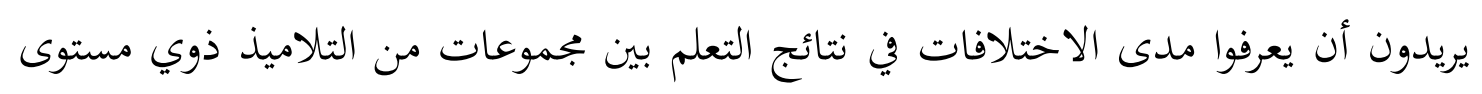

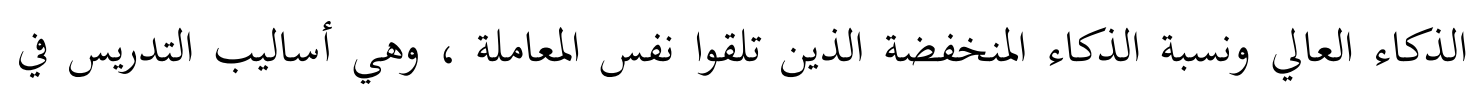
العمل الجماعي والتدريب على المهارات. نتائج بتميع البيانات وحسابها مدرجة أدناه:

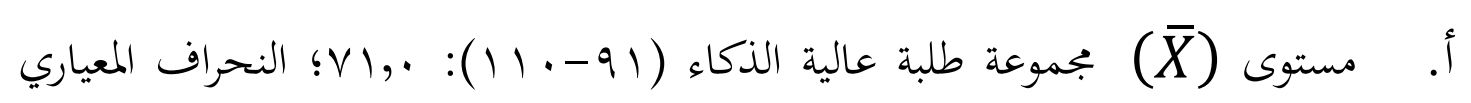
12,5: (SX)

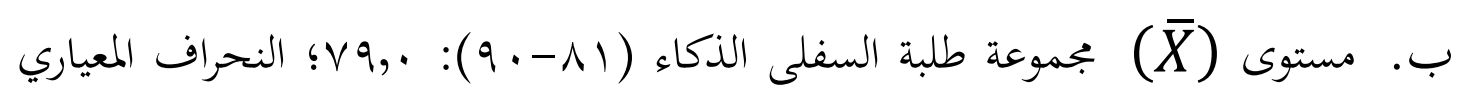

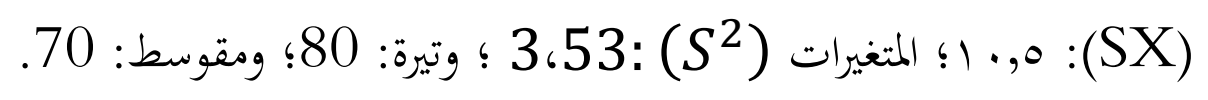

قبل متوسط نتائج تعلم اللغة العربية بين مجموعتين مختلفتين من الذكاء، تم اختبار كلتا

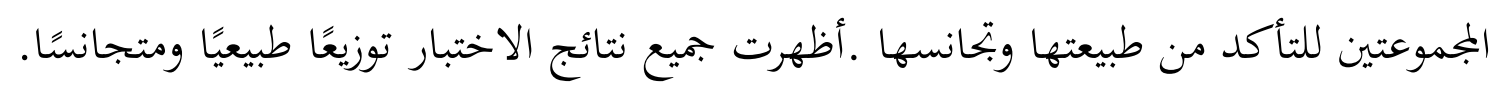

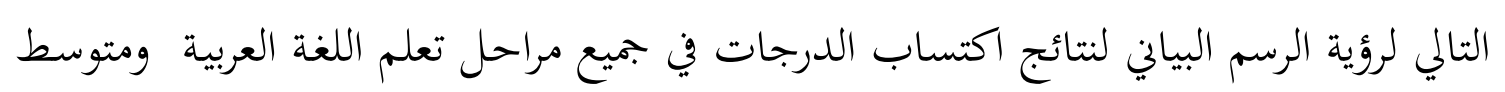

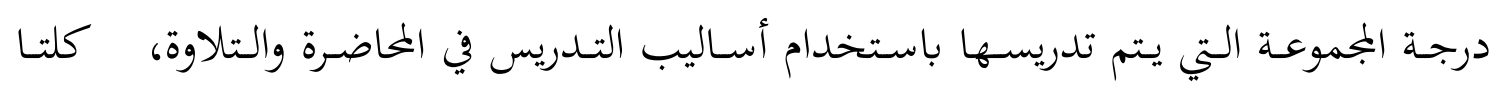
المجموعتين من التلاميذ الحاصلين على مستوى حاصل ذكاء وبجموعات من التلاميذ الحاصلين على حاصل ذكاء منخفض، بادئ ذي بدء ، يتم السعي لتوزيع التردد. 
ب. بيانات عن نتائج تعلم التلاميذ التي يتم تدريسها بواسطة أساليب تدريس العمل الجماعي

$$
\text { والتدريب على المهارات (التجربة). }
$$

البيانات من هذه المجموعة الدراسة، في البيانات الكمية التي تم الحصول عليها من النتائج قبل

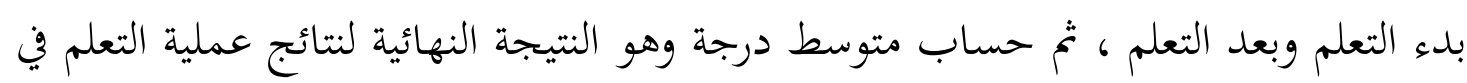
هذه الدراسة.

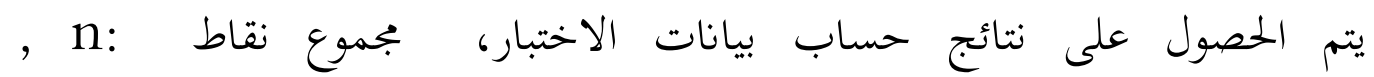

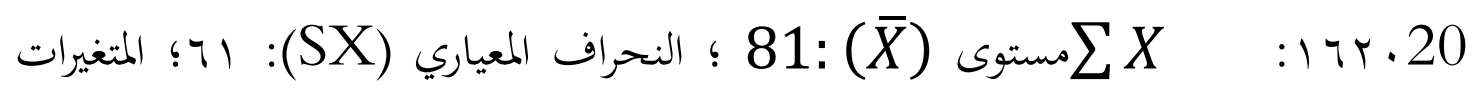
(1) 8،00: $\left(S^{2}\right)$ بعد ذلك ، يتم تصنيف متوسط درجات الاختبار في مجموعتي الذكاء من التلاميذ في المجموعتين العليا والسفلى، من المتوقع أن تمثل هذه المجموعة بجموعة من التلاميذ الذين لديهم

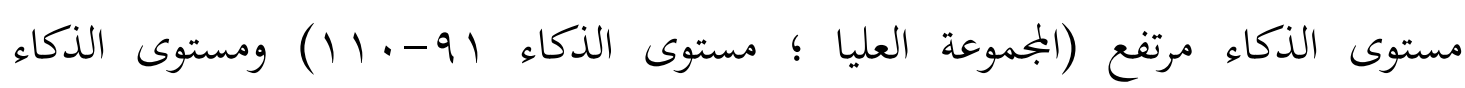

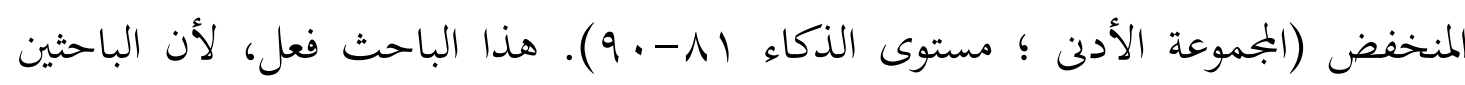

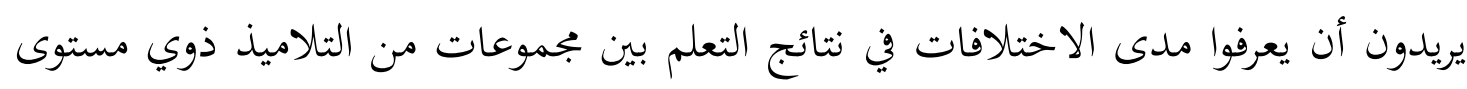

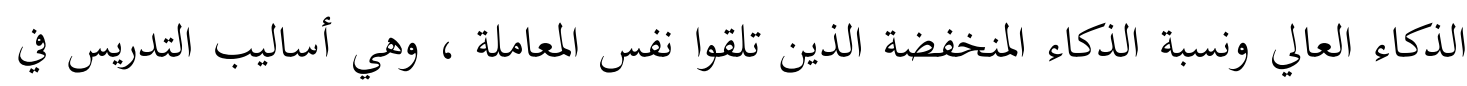
العمل الجماعي والتدريب على المهارات. نتائج بتميع البيانات وحسابها مدرجة أدناه:

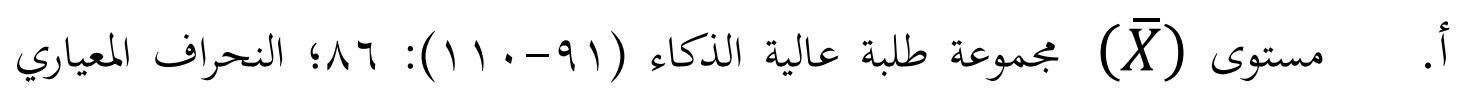
18): (SX)

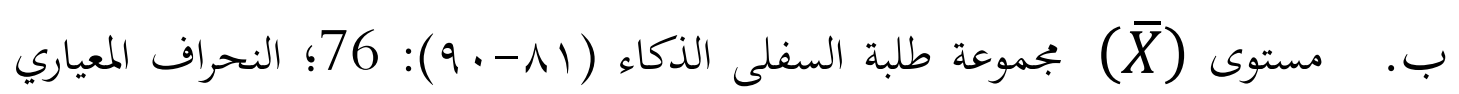

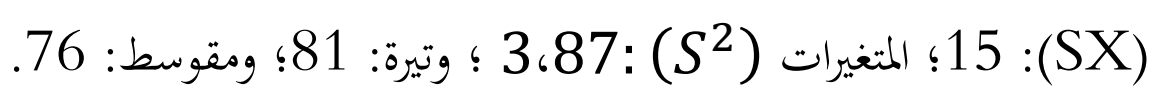

قبل متوسط نتائج تعلم اللغة العربية بين مجموعتين مختلفتين من الذكاء، تم اختبار كلتا المجموعتين للتأكد من طبيعتها وبتانسها. أظهرت جميع نتائج الاختبار توزيعًا طبيعيًا ومتجانسًا.

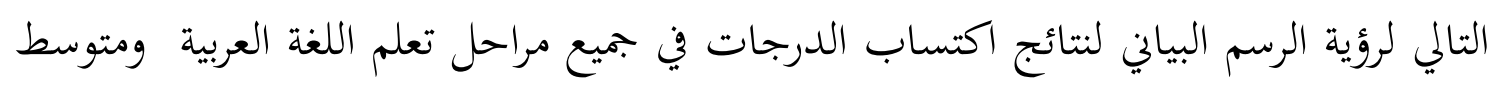

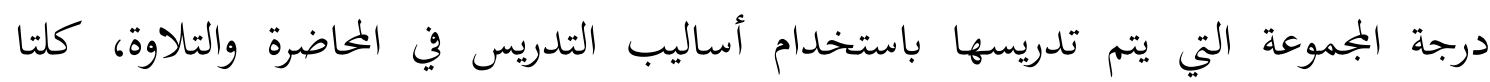


المجموعتين من تلميذ الحاصلين على مستوى حاصل ذكاء وبجموعات من تلميذا الحاصلين على حاصل ذكاء منخفض، بادئ ذي بلد ، يتم السعي لتوزيع التردد.

$$
\text { ع. إختبار السوية }
$$

أ) إختبار السوية تواتر توزيع متوسط الدرجات لمجموعات من التلاميذ ذوي مستوى الذكاء

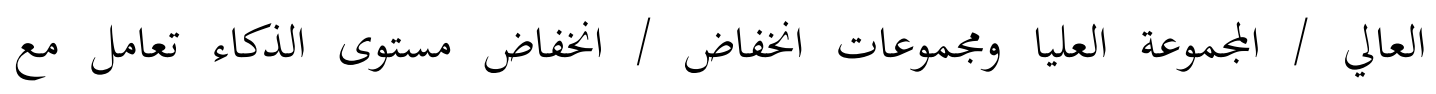
(التحكم). إختبار السوية هو لمعرفة إستواء المواد من متغير البحث. إختبار السوية لهذاء

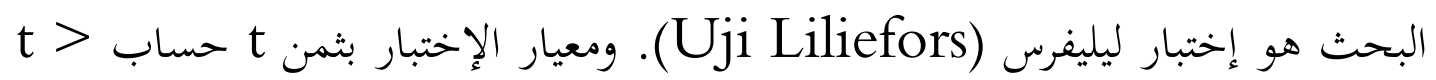

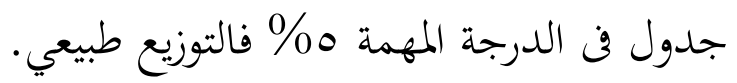

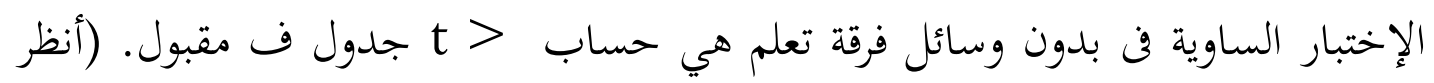
إلى ألملحق). ب) إختبار السوية بيانات عن نتائج تعلم التلاميذ التي يتم تدريسها بواسطة أساليب تدريس العمل الجماعي والتدريب على المهارات (التجربة). إختبار السوية هو لمعرفة إستواء المواد من متغير البحث. إختبار السوية لهذا البحث هو إختبار ليليفرس (Uji Liliefors).

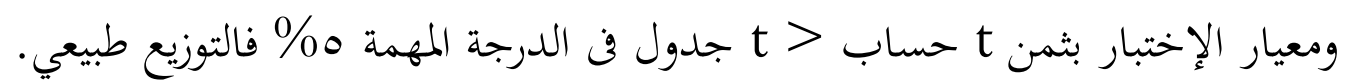
F) إختبار بتحانس، اختبار التجانس مستخدمة في هذا البحث هي معيار الاختبار

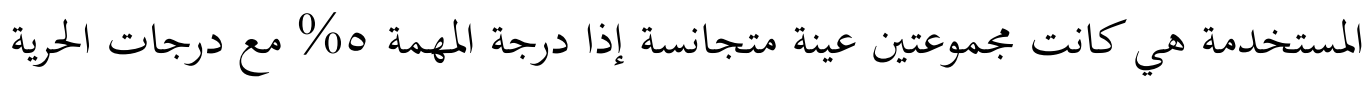

$$
\text { في الكسر والعداد. (DF) }
$$

استنادا إلى استنتاجات تحليل التباين وجود اختلافات في فصل التجربية التي تستخدام طريقة

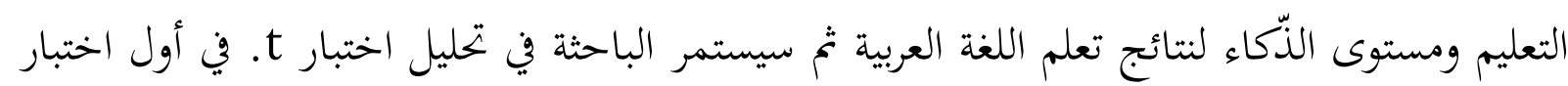
يهدف إلى مقارنة إنجاز بوسائل طريقة التعليم ومستوى الذّكاء لنتائج تعلم اللغة العربية. من عملية حساب الإحصاء يكتسب نتيجة الإختبار t حسابي طريقة التعليم ومستوى الذكاء لنتائج تعلم اللغة

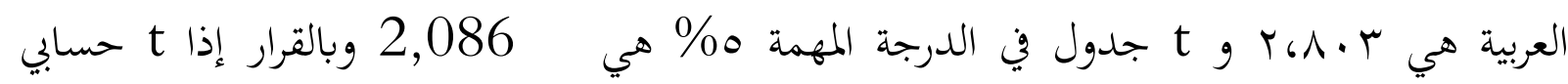

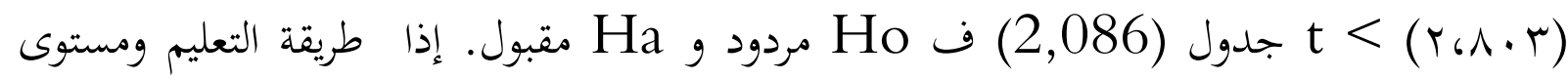

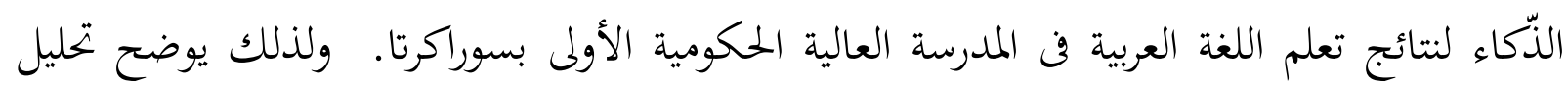


البيانات أعلاه أن تلميذ الذين يتبعون طريقة التعليم ومستوى الذّكاء لنتائج تعلم اللغة العربية التحدث

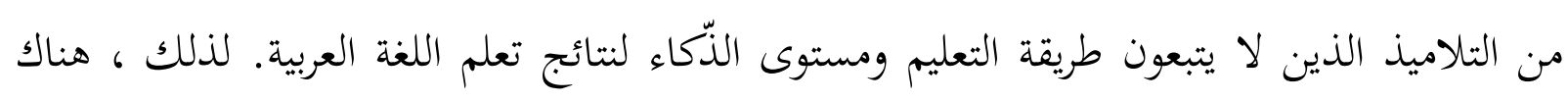

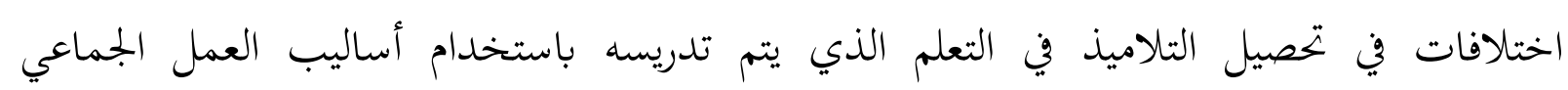
والتدريب على المهارات (التجريبة) أفضل من التلاميذ الذين تم تدريسهم بواسطة أساليب المحاضرة والتلاوة (التحكم).

\section{الخلاصة}

هناك اختلافات كبيرة في تحصيل تعلم اللغة العربية بين التلاميذ الذين يتم تدريسهم باستخدام طريقة

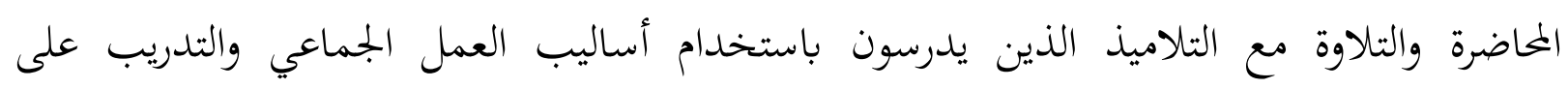

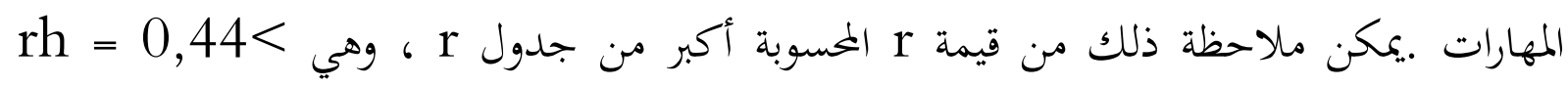

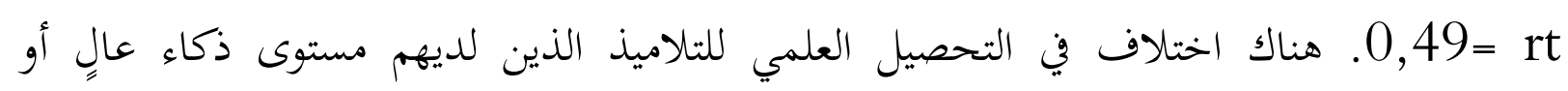
مدرجون في مجموعة مستوى الذكاء الأعلى مقارنة بتلاميذ ذوي مستوى الذكاء المنخفض أو التلاميذ التهيل

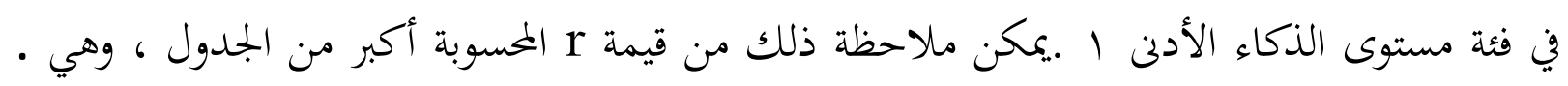
$\mathrm{rh}=0,44<0,78=\mathrm{rt}$

يمكن لطريقة تدريس العمل الجماعي والتدريب على المهارات أن تحسن بشكل كبير من

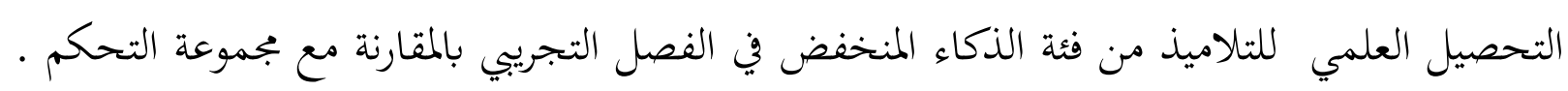
يمكن ملاحظة ذلك من خلال الفرق في متوسط القيمة التي حقتتها المجموعتان حيث المجموعة التجريبية أكبر من المجموعة الضابطة ، وهي: 96> 94 94. 


\section{المراجع}

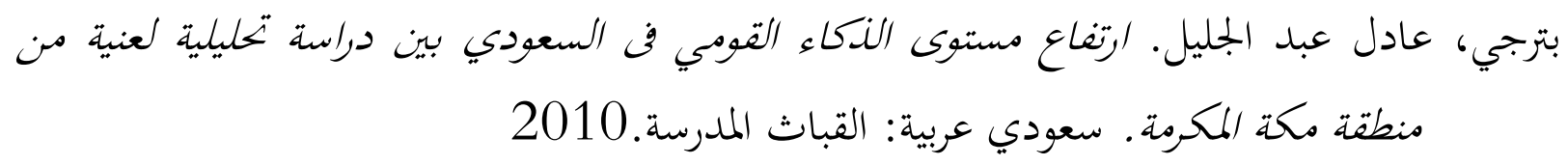

عمار، بشر. اختبارات النكاء: واستخداماتها ماهيتها استخداماتها( استخامها فى رفع سةية الأداء في

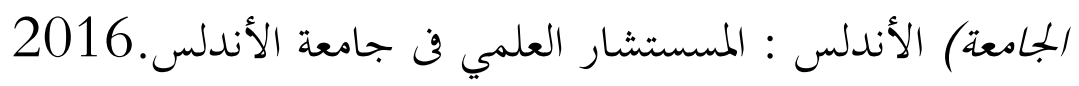

شفاء فوزية، أمى. تطبيق طريقة المحاضرة لترقية مهارة الطلاب في الكلام بالمعهد العصر " دارلحكمة

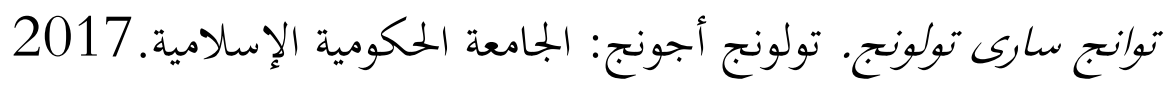

مزدلفة. مشكلات طالبات المستوى الأول طريقة المحضرة عند تعلم اللغة العربية في معهد البرمكاير.

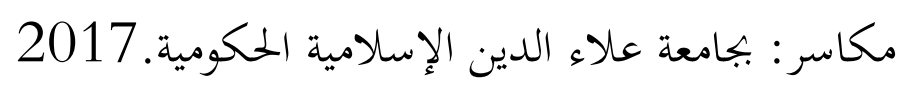

نور كرامة، رشيدة. تطبيق طريقة القراءة المشتركة (Shared Reading) بوسيلة القصص المصورة

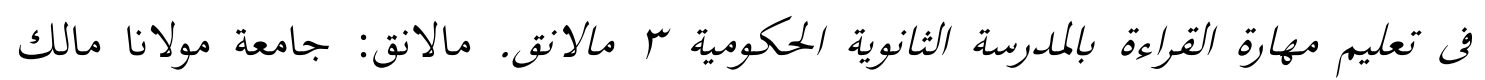

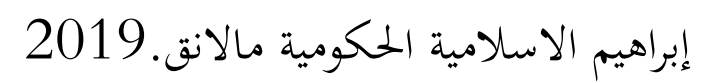

هاشم، أبو السيد. قائمة النكاءات المتعلدة تعريب وتقنين. سعودي : الجمعة الملك السعود.2010

Ahmadi Abu,Dkk. Strategi Belajar Mengajar. Bandung : Pustaka Setia. 2009

Arikunta, Suharsimi. Prosedur Penelitian Suatu Pendekatan Praktik. Jakarta: PT RINEKA CIPTA. 2013

Bischof, L. J. Pengantar Teori Intelegensi Terj. Hanafi Abdillah. Surabaya : Usaha Anda. 1954

Eysenck, H.J. \& Kamin, L. Inteligence. London : The Battale For Mind Pan Books Caveve Palce. 2011

Hasibuan, jj dkk, Proses Belajar mengajar. Bandung : Rosda. 2006

Kayatun, Sri. Penggunaan Metode Kerja Kelompok Untuk Meningkatkan Hasil belajar Matematika Sekolah Dasar. Pontianak: Universitas tanjungpura. 2013

Mangkunegara,AA dan Prabu Anwar. Perkembangan Intelegensi Siswa dan pengukuran IQnya. Bandung : Angkasa. 1993

Masrun. Aliran-aliran psikologi. Yogyakarta : UGM. 1977 
Moleong, Lexy J. Metode Penelitian Kualitatif. Bandung: PT. Remaja Rosdakarya. 2013 Mugihardjo. "Perbedaan Intelegensi Qosien (IQ) antara anak yang latar belakang pekerjaan orang tua berbeda pada siswa SMPN II Purworejo." Karya Ilmiah . Yogyakarta : IKIP. 1984

Muhari . "Suasana rumah dan prestasi belajar suatu studi tentang pengaruh suasana rumah terhadap prestasi belajar para siswa SMTP di Jawa Timur ", Disertasi, Yogyakarta : UGM. 1983

Munandar. S.C. Utami. Pemanduan Siswa berbakat. Jakarta : Rajawali. 1982

Nazir Moh. Metode Penelitian. Jakarta : Ghalia Arab. 2003

Pusat Bahasa. KBBI (Kamus Besar Bahasa Indonesia). Jakarta: Gramedia Pustaka Utama. 2008

Rakhman A.N. Hubungan antara IQ dan Motivasi berprestasi dengan prestasi pabrikasi logam dasar siswa kelas I rumpun pekerjaan logam program study mesin di STM II Yogyakarta tahun 1989/1990. Skripsi. Yogyakarta : IKIP. 1990

Raven J.C . Guide to the standard Proressive Matrices Sets $A, B, C, D$ dan E , Yogyakarta : UGM. 1960

Roestiyah. Didaktik Metodik. Jakarta : Bumi Aksara. 1982

Roestiyah. Strategi Belajar Mengajar. Jakarta : Rineka. 2001

Rohani Ahmad dkk. 1991. Pengelolaan pengajaran. Jakarta : Rineka Cipta. 1991

Rowell, J.A. Experiment and Theory : Their Interrelation and balance in Teaching of science with special reference to high school in south Australia.. Unpublished Doctoral Thesis. South Australia : The University of Adelaide. 1969

Sairuddin. Kamus Arab Indonesia. Jombang: Lintas Media. 2010

Singarimbun Masri dan Effendi Sopian. Metode Penelitian Survai. Jakarta : LP3ES. 2010

Sopandi, Ahmad. Meningkatkan Keterampilan membuat Palai Rinuak melalu Metode Latihan pada Anak Tunagrahita Ringan. Padang:UNP. 2013

Sugiyono. Metode Penelitian Kuantitatif Kualitatif dan R\&D. Bandung: Alfabeta. 2015

Singgih D. Gunarsa. Psikologi Perkembangan. Jakarta : Gunung Mulia. 2017

Sudjana Nana. Dasar-dasar proses belajar mengajar. Bandung : Sinar baru algensindo. 2004

Suparno dkk. Dimensi-dimensi mengajar. Bandung : Sinar Baru. 1988

Suramto. Pengaruh ujian satu kali pada akhir semester terhadap prestasi belajar mahasiswa fakultas psikologi UGM, Laporan Penelitian. Yogyakarta : UGM. 1978

Tyler L.E. The psychology of human defferences. Second edition. New York : Appletown Century Crafts. Inc. 1965

Viktor Serebriakoff. "How Intelligent Are You ?". London : Published by Arrangement with the english library, Ltd. 2014

Zimbardo PG. Essentials of Psychology and life. Glenview, Illinois : Scott Foresman and Company. 2004 